\title{
DETERMINING THE ROLE OF CONFLICT MANAGEMENT STRATEGIES ON ORGANIZATIONAL PERFORMANCE: A MEDIATING ROLE OF EMPLOYEE'S JOB SATISFACTION
}

\author{
Syeda Batool ${ }^{1}$ and Fiza Hayat ${ }^{2}$
}

\begin{abstract}
Conflict Management is one of the essential elements in causal and professional life for enhancing their performance and to bring better results in intense pressure. Although studies which explore the effect of these on job satisfaction are very few and therefore there is a need to check the impact of these form of strategies on job satisfaction. Although according to the studies each and every style of conflict management does not relate with job satisfaction and therefore the major need to associate this style with organizational performance. Thus, a quantitative study has been conducted in the commercial banking $g$ sector of Pakistan through closed ended questionnaire. Analysis was made by SMART PLS and the results of the study indicated that each and every style of conflict management does not result in job satisfaction not in the betterment of organizational performance.
\end{abstract}

Keywords: Conflict Management, Employee's Job Satisfaction, Organizational Performance \& Commercial Banking Sector.

\section{INTRODUCTION}

In recent times corporation attempts to increase the level of performance by solving multiple hurdles like conflicts, Umair, Aslam and Yousuf (2018) declares that there are multiple types of conflict conditions and taken as a bad tool of management. Organization tries to escape from

1 and 2 KASBIT, Karachi, Pakistan 
conflicts wherever it is possible and when the milestones are not achieved by the management. Conflicts might happen. Francis (2018) explains that conflicts is caused due to disagreement between the stakeholder's interest, values and goals and creates a negative perception between both the parties. Wanyonyi, Kimani and Amuhaya (2015) contributed towards the study that a conflict caused in the organization occurs when interest, values and goals of every individual and groups are not parallel.

Awan and Saeed (2015) emphasized that conflict is a normal and unavoidable phenomenon, playing a vital part in every individual's daily life \& should be kept at a manageable level. In the organizational settings conflicts are unpredictable but if properly coped by executives, can positively impact on employee satisfaction as well as on the performance level (Olang, 2017).Reason for organizational conflicts might be lack of resources, behavior regulations, ambiguous jurisdiction, communication barriers, disagreeing patterns, force and fear (Umair, Aslam \& Yousuf, 2018). However, some conflicts are for the betterment of the firm (Pratiwi, 2017) \& if managed within time, it results in enhancing workers satisfaction, job performance and ultimately increases performance of the organization (Echaaobari, Ihunda \& Adim, 2018). Thus a productive firm is not unbound from all sorts of conflicts due to the changes of goals, values, culture, attitudes, beliefs, skill and the way of thinking of the employees (Pratiwi, 2017). Hence legitimate to believe that numerous strategies could solve the conflicts efficiently and conflict is taken as a positive measure because it can affect the level of profitability (Taher \& Gomes, 2018)

\section{STATEMENT OF PROBLEM}

Taher \& Gomes (2018) explained that the executives of an organization devote half of their time in resolving the conflicts of employees and create such environment where the riot and clash between each other can be managed. Awan \& Saeed (2015) emphasizes that; if conflict is not coped properly it will have a damaging outcome on the organization performance which 
will lead towards greater economic loss. Existing Literature by Ouedraogo \& Leclerc (2013) that employee job satisfaction has a positive impact on the organizational performance and studying the previous studies that satisfied employees can enhance the level of productivity of the organization. Another research by Mehrad (2015) concluded that there are different types of conflict management strategies for different level of conflicts and application of most appropriate is essential for employee satisfaction. Thus legitimate to believe conflict management does not alter organizational performance directly but employee job satisfaction which acts as a mediator between conflict management. Thus there is a need to check effect of various conflict management strategies i.e. accommodating Style, compromising style, avoidance Style and dominating Style on job satisfaction of employees (Weerarathna, 2017).

\section{THEORATICAL FRAMEWORK}

AL-Shourah and Abdullah (2015) defines that conflict management has gotten major importance by researchers. Similarly, Sammy (2016) indicated that organizational performance is perceived to be influenced by accommodating, compromising, dominating and avoiding strategies \& each strategy has its unique contribution with respect to individual and organization. However, conflict management and organization performance is backed up by employee job satisfaction (Nwagboa, 2018). Therefore, this study will check the effect of conflict management strategies on organizational performance through $\mathrm{h}$ the mediation of job satisfaction.

\section{SIGNIFICANCE OF THE RESEARCH}

Mayowa (2015) proven in the study that the research on conflict management has become very important in many organizations especially in the manufacturing sectors. On the other aside, Shaheryar (2016) explained that if conflict is managed properly, it can strengthen one's relationship and can have positive impact on the performance of an organization. Therefore 
this study is pretty effective and useful in the domain of management as it describes about the impact of conflict management on performance of the organization as well as on job satisfaction. Thus, will aid knowledge in a unique way and provide blend of knowledge associated with the concept of management and human resource management.

\section{LITERATURE REVIEW}

\section{Compromising Style and Organizational Performance:}

Vokic and Sontor (2019) stated that compromising is the style of conflict management which has been applied most extensively in the organizational setting. Longe (2015) also provided empirical evidence to show positive link between compromising and organizational performance. This strategy delivers a higher quality of decision making than any other style and boost up the level of productivity in the sector (Vokic \& Sontor, 2019). Managers are more likely to use this style in order to minimize the conflicts and provide a high confidence and trust level in organizational members (Longe, 2015)

\section{Compromising Style and Employee's Job Satisfaction:}

Momanyi and Juma (2016) found that superior authority uses compromising style in their decision making which helps to enhance the satisfaction among employees which is beneficial for organization performance. Taher and Gomes (2018) also found out that compromising is the point of intersection of the two dimensions, that is, a middle ground position where a party has an intermediate level of concerns for both parties. Therefore it was observed in the study that compromising style has impacted positively in the organization by encouraging innovativeness, improved decision making process in managing conflicts and increased the level of job satisfaction of employees.

\section{Accommodating Style and Organizational Performance:}

Shaheryar (2016) stated that accommodating style was found out to be more operative and reduces the conflicts and stress at work place. Style aids managers to work creatively towards 
goals and satisfaction of both the parties. Moreover, accommodating style was found out to be more useful style which has positively impacted on the performance level of the organization. Prasad and Radhika (2018) explained the use of accommodation often occurs when one of the parties wishes to keep the peace or perceives the issue as minor. Employees who use accommodation as a primary conflict management strategy, however, may keep track and develop resentment.

\section{Accommodating Style and Employee's Job Satisfaction:}

Alzahrani (2013) assumed that in according to accommodating style party sacrifices its rights and needs to satisfy other parties. It states that this style is adopted by people who tend to minimize the differences with other parties and stress their commonalities. It was confirmed that job satisfaction was linked with accommodating style because satisfied individuals usually are more committed to their job and have lower intention to leave the organization. George, Miroga and Omweri (2013) found that accommodation results in a loose but a good relationship between parties is created. This relationship is created when people appeal for co-operation and try to reduce tension and stress by offering reassurance and support for the other person's views. \& has positive effect on job satisfaction.

\section{Dominating Style and Organizational Performance:}

Francis (2018) claimed that dominating style of conflict management involves one party winning and the other losing or well known as a competition. Thus, each party trying to achieve what they want over the other party (Longe, 2015). This actually happens when managers force employees with this style to come up with the solution because for them goals of the organization are more significant compared to the concerns of the employees. Thus, can affect the performance of the employees since managers over power their employees thus a style seen to be partly effective than appropriate for the situation. According to Longe (2015), through this strategy top level management forces the employees to follow their procedures in order to 
achieve the objectives without looking at the concerns of the employees. This causes a decline in the organizational performance because the employees may not be committed with their managers as well as to the organization.

\section{Dominating Style and Employee's Job Satisfaction:}

Kassim, Manaf, Abdullah, Osman and Salahuddin (2018) explained that dominating style is negatively associated with job satisfaction. This is because dominating style is only satisfying personal interest without considering the interest of the other party at all. This style disallowed employees to express their opinion and involved partially in decision-making process in order to solve the conflict. Consequently, unsolved conflict will affect employees' job satisfaction and they are not motivated to commit for their organization. George, Miroga and Omweri (2013) assumed that the competing or dominating style involves the use of coerciveness and other forms of power to dominate other people or groups in order to pressurize them in accepting your own view of the situation. It involves being no co-operative but assertive, working against the wishes of the other party and engaging in a win-lose competition or forcing through the exercise of authority.

\section{Avoidance Style and Organizational Performance:}

Prasad and Radhika (2018) observed that most top level management gives authority to employees to resolve conflicts because it enhances their power of decision. Thus, this style was positively linked up and impacted significantly with the performance level of the organization. Sammy (2016) claims, the avoiding style involves restricting or sidestepping in conditions when both employees and managements avoid confronting each other, then harmony is achieved and the possibility of having conflicts is minimal, thus it is a conducive environment for work leading to employee improved performance. 


\section{Avoidance Style and Employee's Job Satisfaction:}

Alzahrani (2013) founded that individuals who have a low concern for themselves and for others adopt avoiding style because avoiders ignore the problem and do not attempt to understand and handle conflicts at all. This style is inappropriate when the issues are important to a party, when a person is in charge of making decisions, or when a swift action is required to deal with a situation. There is no significant association between accommodating style and job satisfaction. Kassim, Manaf, Abdullah, Osman and Salahuddin (2018) enlightened that avoiders ignore the problem and refuse to make any effort to resolve the conflict. It was found that avoiding styles were negatively associated with job satisfaction because in avoiding style both parties are not putting any effort to solve the conflict. These styles disallowed employees to express their opinion and involved partially in decision-making process in order to solve the conflict. Consequently, unsolved conflict will affect employees' job satisfaction and they are not motivated to commit for their organization.

\section{Employee Job Satisfaction and Organizational Performance:}

Miah (2018) emphasizes that job satisfaction is an essential tool with definite impact on work place because when employee is satisfied to their job than it creates charming pressure within organization. In fact, organizations having highly satisfied employees who even not in stress undoubtedly will attain higher levels of performance than the others (Ouedraogo and Leclerc, 2017)

\section{RESEAERCH METHODOLOGY}

\section{Research Design}

The philosophy behind this study is epistemology and the stance is post-positivism as the study is trying to uncover ideas which will aid to knowledge building through quantitative approach (Saunders et al., 2009). 
The purpose of research is correlational and study setting was non-contrived as the study was conducted with the ease of respondents but the framework was developed through merging prior studies (Sekaran \& Bougie, 2016). The research strategy was survey and the time horizon was cross-sectional as this study was based on data collection through closed ended questionnaire which are analyzed once through SMART-PLS (Saunders et al., 2009).

\section{Sampling Design}

This study has been done in the commercial \& private banking sector of Pakistan as sector is majorly focused on profit generation which force enormous burden on employees which ultimately resulted in decrease of motivation. Especially in private sector banks where retention of employees is a real challenge for the managers (Rashidi \& Rahman, 2013). Thus this strategy takes the sample of 100 middle level managers from different commercial banks and use quota sampling to select those middle level managers who have experienced of banking sector as well as regarding management of conflict being a supervisor.

\section{STATSITICAL TESTING}

\begin{tabular}{|l|c|c|}
\hline R Square: & & \\
\hline & R Square & R Square Adjusted \\
\hline Employee Job Satisfaction & 0.720 & 0.695 \\
\hline Organizational performance & 0.749 & 0.721 \\
\hline
\end{tabular}

Table 1: Quality Criteria (Predictive Accuracy)

\begin{tabular}{|l|l|l|l|l|l|l|}
\hline & $A S$ & $A V S$ & $C S$ & $D S$ & $E J S$ & $O P$ \\
\hline$A S$ & 0.799 & & & & & \\
\hline$A V S$ & 0.793 & 0.593 & & & & \\
\hline$C S$ & 0.857 & 0.759 & 0.847 & & & \\
\hline$D S$ & 0.757 & 0.715 & 0.752 & 0.808 & & \\
\hline$E J S$ & 0.795 & 0.787 & 0.745 & 0.742 & 0.871 & \\
\hline OP & 0.758 & 0.727 & 0.701 & 0.722 & 0.837 & 0.754 \\
\hline
\end{tabular}

Table 2: Discriminant Validity Heterotrait-Monotrait Ratio (HTMT) 


\begin{tabular}{|l|l|l|l|l|}
\hline & $\begin{array}{l}\text { Cronbach's } \\
\text { Alpha }\end{array}$ & rho_A & $\begin{array}{l}\text { Composite } \\
\text { Reliability }\end{array}$ & AVE \\
\hline $\begin{array}{l}\text { Accommodating } \\
\text { Style (AS) }\end{array}$ & 0.81 & 0.82 & 0.876 & 0.639 \\
\hline Avoiding Style (AvS) & 0.875 & 0.878 & 0.915 & 0.728 \\
\hline $\begin{array}{l}\text { Compromising Style } \\
\text { (CS) }\end{array}$ & 0.869 & 0.87 & 0.91 & 0.717 \\
\hline $\begin{array}{l}\text { Dominance Style } \\
\text { (DS) }\end{array}$ & 0.823 & 0.83 & 0.882 & 0.653 \\
\hline $\begin{array}{l}\text { Employees Job } \\
\text { Satisfaction (EJS) }\end{array}$ & 0.894 & 0.897 & 0.926 & 0.759 \\
\hline $\begin{array}{l}\text { Organizational } \\
\text { Performance (OP) }\end{array}$ & 0.717 & 0.817 & 0.826 & 0.568 \\
\hline
\end{tabular}

Table 3: Construct Reliability and Validity

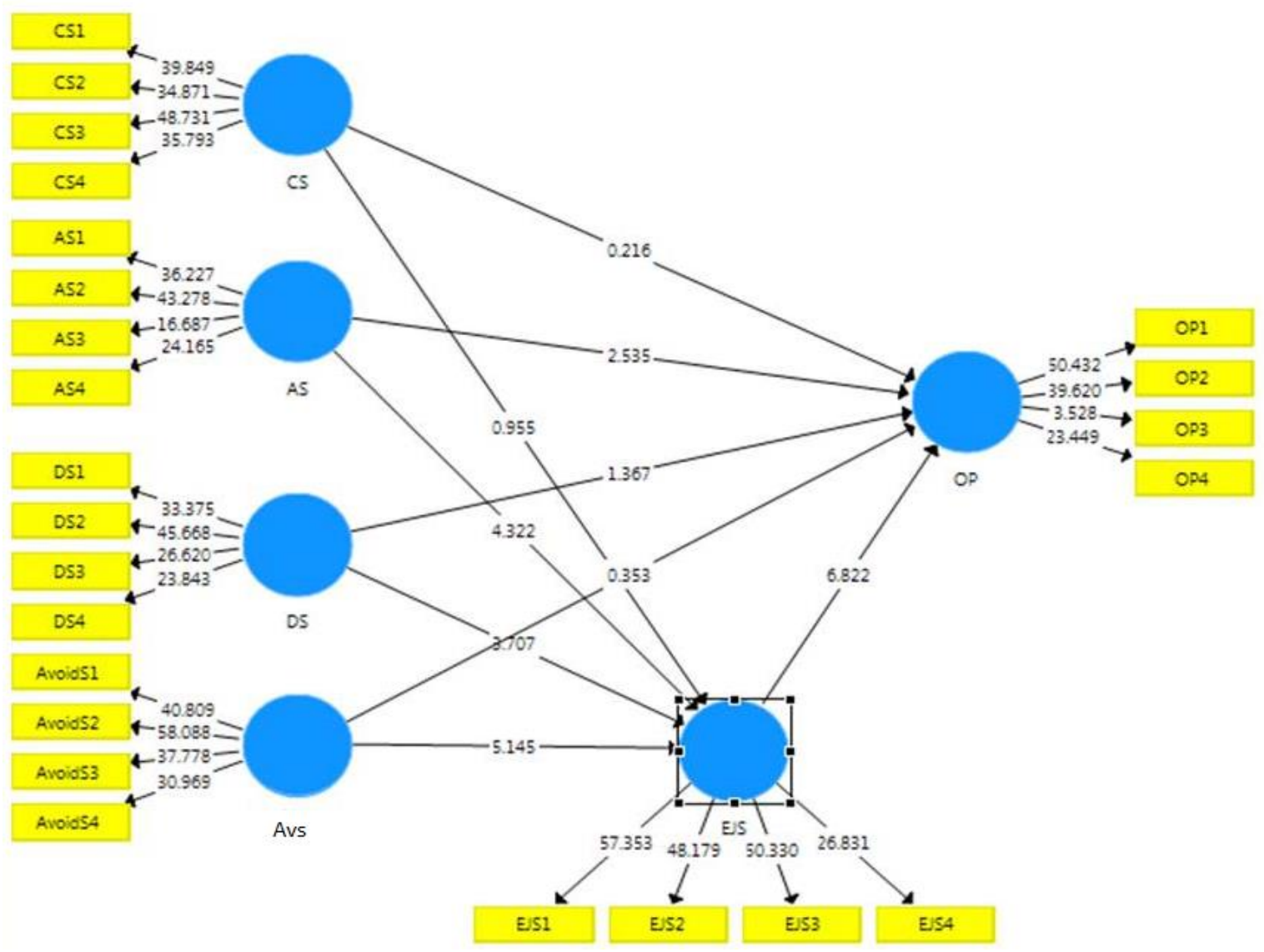

Figure 1: T-Statistics and Path Coefficient for conflict management strategies on organizational performance with mediation of employee job satisfaction 


\begin{tabular}{|l|c|c|c|c|c|}
\hline & $\begin{array}{l}\text { Original } \\
\text { Sample (O) }\end{array}$ & $\begin{array}{l}\text { Sample } \\
\text { Mean (M) }\end{array}$ & $\begin{array}{l}\text { Standard Deviation } \\
(\text { STDEV })\end{array}$ & $\begin{array}{l}\text { T Statistics } \\
(\mid \mathrm{O} / \mathrm{STDEV})\end{array}$ & $\begin{array}{l}\text { P } \\
\text { Value } \\
\mathrm{s}\end{array}$ \\
\hline $\begin{array}{l}\text { AS -> } \\
\text { EJS }\end{array}$ & 0.3 & 0.296 & 0.069 & 4.322 & 0.000 \\
\hline $\begin{array}{l}\text { AS -> } \\
\text { OP }\end{array}$ & 0.181 & 0.184 & 0.071 & 2.535 & 0.012 \\
\hline $\begin{array}{l}\text { Av S -> } \\
\text { EJS }\end{array}$ & 0.344 & 0.34 & 0.067 & 5.145 & 0.000 \\
\hline $\begin{array}{l}\text { AvS -> } \\
\text { OP }\end{array}$ & 0.036 & 0.048 & 0.103 & 0.353 & 0.724 \\
\hline $\begin{array}{l}\text { CS -> } \\
\text { EJS }\end{array}$ & 0.069 & 0.074 & 0.073 & 0.955 & 0.955 \\
\hline $\begin{array}{l}\text { CS -> } \\
\text { OP }\end{array}$ & -0.013 & -0.014 & 0.061 & 0.216 & 0.829 \\
\hline $\begin{array}{l}\text { DS -> } \\
\text { EJS }\end{array}$ & 0.214 & 0.219 & 0.058 & 3.707 & 0.000 \\
\hline $\begin{array}{l}\text { DS-> } \\
\text { OP }\end{array}$ & 0.155 & 0.147 & 0.113 & 1.367 & 0.172 \\
\hline $\begin{array}{l}\text { EJS -> } \\
\text { O P }\end{array}$ & 0.56 & 0.553 & 0.082 & 6.822 & 0.000 \\
\hline
\end{tabular}

\section{Table 4: Path Coefficients}

Table 4 indicates that among all the relationship avoiding style and dominance style are those strategies of conflict management which have an impact on employee job performance but failed to affect organizational performance. However, compromising is the only style of conflict management which neither have impact on employee job satisfaction nor on organizational performance.

\section{CONCLUSION AND DISCUSSION}

Analysis indicated that employee job satisfaction is always related with employee job satisfaction which is consistent with Miah (2018) and Ouedraogo and Leclerc (2017) etc. Although each and every style of conflict management strategy does not have relationship with the employee satisfaction as compromising style failed to affect that. Hence it is optimal to believe Sammy (2016) that each style has its own purpose in the organization and therefore it's a conceptual difference between the findings and the indications made by Nwagboa (2018). 


\section{RECOMMENDATIONS AND AREA FOR FUTURE RESEARCH}

This study has only been conducted through the reference of commercial banking sector and the results are not reflected upon government sector, Islamic and micro-finance banks. Moreover, the findings might also be enhanced through comparing different industries with the banking sector. Last but not the least findings might be optimized through linking these with the moderation of gender to check the conflict management strategies preferred by both form of gender. 


\section{REFERENCES}

AL-Shourah, A. A. S., \& Abdullah, A. S. (2015). The Impact of Conflict Management on Organizational Effectiveness (A Case Study: Ministry of Higher Education of Jordan). European Journal of Business and Management, 7(36), 75-85.

Alzahrani, M. (2013). A comparative study of the relationships between conflict management styles and job satisfaction, organizational commitment, and propensity to leave the job among Saudi and American universities' faculty members (Doctoral dissertation, Florida Atlantic University).

Echaaobari, S. G., Ihunda, C. C., \& Adim, V. C. (2018). Collaboration Strategy and Employee Performance in Oil Producing Companies in Port Harcourt, Nigeria. International Journal of Social Sciences and Management Research, 4(3).

Francis, J. S. (2018). Conflict Management Styles and Employee Performance in Public Hospitals in Nyeri County, Kenya. 1-88.

George, D. E., Miroga , D. B., \& Omweri, A. N. (2013). Organizational Conflict Management Strategies on Employee Job Satisfaction: A case study of Nzoia Sugar Company. European Journal of Business and Management, 5(3), 177-186.

Kale, E. (2018). The effect of conflict management styles on task performance. International Journal of Tourism, Economic and Business Sciences, 2(2), 165-175.

Kassim, M. A., Abdullah, M. S., \& Mansor, M. F. (2017). The Mediating Role of Conflict Management Styles Between Organizational Justice and Affective Commitment Among Academic Staffs in Malaysian Public Universities. MATEC Web of Conferences, 150, 1-9.

Kassim, M. A., Manaf, A. H., Abdullah, M. S., Osman, A., \& Salahudin, S. N. (2018). Conflict Management Styles and Job Satisfaction: A Study Among Malaysian Public Universities’ Academicians. Asian Journal of Social Sciences \& Humanities, 7(4), 1121.

Longe, O. (2015). Impact of Workplace Conflict Management on Organizational Performance: A Case of Nigerian Manufacturing Firm. Journal of Management and Strategy, 6(2), 83-92.

Manjula, N., \& Thilagavathy, N. (2018). Job Satisfaction and Conflicts among LIS Professionals in Academic Institutions in Chennai: An Evaluative Study. Indian Journal of Information Sources and Services, 8(3), 23-25. 
Mayowa, S. O. (2015). Industrial conflict and its management in selected Nigerian manufacturing companies. International Journal of Organizational Leadership, 430439.

McClinton, P. (2014). Leadership \& Conflict Management. 1-9.

Mehrad, A. (2015). Conflict Management Styles and Staff' Job Satisfaction at Organization. Journal of Educational, Health and Community Psychology, 4(2), 86-93.

Miah, M. M. (2018). The impact of employee job satisfaction toward organizational performance: A study of private sector employees in Kuching, East Malaysia. International Journal of Scientific and Research Publications, 8(12), 270-278.

Momanyi , D. K., \& Juma, D. D. (2016). The influence of conflict management strategies on employee satisfaction: a case study of kcb bank kenya limited, head office. International Academic Journal of Human Resource and Business Administration, 2(2), 130-144.

Nwagboa, I. C. (2018). Conflict management and employee's job satisfaction of private security firms in Rivers State. Scholarly Journal of Science Research and Essay, 7(1), 8-12.

Ouedraogo, A., \& Leclerc, A. (2013). Job satisfaction and organizational performance: evidence from canadian credit union. Journal of Organizational Culture, Communications and Conflict, 17(1), 35-50.

Ouedraogo, A., \& Leclerc, A. (2017). Job satisfaction and organizational performance: evidence from canadian credit union. journal of organizational culture, communications and conflict, 1-21.

Prasad, D. V., \& Radhika, B. (2018). Impact of Workplace conflict management strategies" on organizational performance (with reference to private sector Banks). International Journal of Pure and Applied Mathematics, 118(15), 71-76.

Pratiwi, M. A. (2017). A study of conflict management style and employee's job satisfaction at karimun general hospital (Indonesia). 14-97.

Rashidi, A. A., \& Rahman, D. M. (2013). Retention issues in banking industry of Pakistan: A case study of Habib Metro and Soneri Bank. Journal of Independent Studies and Research, 11(1), 57-67.

Sammy, C. M. (2016). Influence of implementation of conflict management strategies on employees performance: a case of kenya power company, nairobi county. 1-66. 
Saunders, M., Lewis, P., \& Thornhill, A. (2009). Research methods for business students. Pearson education.

Sekaran, U., \& Bougie, R. (2016). Research methods for business: A skill building approach. John Wiley \& Sons.

Shaheryar. (2016). General Preference of Conflict Management Styles of NADRA Employees. International Journal of Economics \& Management Sciences, 5(3), 1-3.

Taher, M. A., \& Gomes, K. (2018). Exploring the Relationship between Conflict Management Style and Organizational Performance: An Empirical Study in the Organizations of Bangladesh. Global Journal of Management and Business Research: A Administration and Management, 18(4), 36-52.

Umair, M., Aslam, S., \& Yousuf, H. (2018). The Effect of Conflicts in Organizational Sectors in Pakistan. Science, Technology \& Public Policy, 2(1), 1-4.

Vokić , N. P., \& Sontor, S. (2019). Conflict Management Styles in Croatian Enterprises - The Relationship between Individual Characteristics and Conflict Handling Styles. FEBWORKING Paper Series, 1-22.

Wanyonyi, B. E., Kimani, D. C., \& Amuhaya, D. M. (2015). Conflict Management Styles Influencing Organizational Commitment among Kenya Seed Company Employees, Kenya. International Journal of Academic Research in Business and Social Sciences, 5(11), 265-276.

Weerarathna, R. S. (2017). Research Gaps in Organizational Conflicts: Future Research Perspectives. International Journal of Human Resource Studies, 7(4), 240-252. 